Visca R Yuanita, Tri Kurniastuti \& Palupi Puspitorini, 2016. Respon Pupuk Kandang Kambing Dan Pupuk Npk Pada Pertumbuhan Dan Hasil Tanaman Terung Hijau (Solanum Melongena L.). Journal Viabel Pertanian. (2016), 10(1)-53-62

\title{
RESPON PUPUK KANDANG KAMBING DAN PUPUK NPK PADA PERTUMBUHAN DAN HASIL TANAMAN \\ TERUNG HIJAU (Solanum melongena L.).
}

\author{
Visca R Yuanita, Tri Kurniastuti, Palupi Puspitorini \\ Fakultas Pertanian Program Studi Agroteknologi
}

\begin{abstract}
Research about influence of goat manure and NPK fertilizer on the growth and yield of green eggplant (Solanum mengolena $\mathbf{L}$.) has been conducted in field village farmer-owned Semen Gandusari District of Blitar which took place in March-April 2016. The aim of this study was to know the interaction for among goat manure and NPK fertilizer on the growth and yield of green eggplant as well as the effect of each factor. This study uses Randomaized Complete Block Design (RCBD) factorial consisting of 16 treatment and each 3 replicates ie: P0M0, P0M1, P0M2, P0M3, P1M0, P1M1, P1M2, P1M3, P2M0, P2M1, P2M2, P2M3, P3M0, P3M1 , P3M2, P3M3. The data taking were plant height, leaf number, fruit length, fruit diameter and weight of fruit per plant. The data were analyzed to $\mathrm{F}$ test as followed by a $5 \%$ test Honestly Significant Difference (HSD) error level of 5\%. The experimental results very significant effect on plant height, leaf number, fruit length and weight of fruits per plant and the effect is not noticeable to the diameter of fruit plants green eggplant. The combined use goat manure $750 \mathrm{~g} /$ plant and NPK fertilizer $60 \mathrm{~g} /$ plant (P2M3) is proper fertilization to improve the growth and best yield of green eggplant with the highest total weight of the fruit crop that yields 1576.6 grams
\end{abstract}

Keyword: eggplant, NPK fertilizer, goat manure

\section{PENDAHULUAN}

Terung (Solanum melongena L.) merupakan salah satu komoditas hortikultura yang mempunyai sifat mudah rusak (perishable). Buah terong ( biasa ) mengandung vitamin A $(4,78 \%)$, kandungan vitamin C $(12,8 \%)$, kadarabu $(5,8 \%)$, karbohidrat $(28,7 \%)$, protein $(34,8 \%)$, air $(86,1 \%)$, zat besi $(6,8 \%)$ dan kalsium $(70,2 \%)$. Pada buah terong ungu kandungan terong ungu memiliki vitamin $\mathrm{A}$ $(4,8 \%)$, kandungan vitamin C $(13,1 \%)$, kadar abu $(3,9 \%)$, karbohidrat $(28,7 \%)$, kandungan protein $(34,8 \%)$, air (81,6\%), za tbesi (12,5\%), dan kandungan kalsiumnya (75\%) (Rukmana, 1999).

Terung merupakan tanaman yang membutuhkan hara yang cukup tinggi dan biasanya dilakukan pemupukan (Rubaztky dan Yamaguchi 1999). Secara umum, tanaman terung membutuhkan pupuk N sebanyak $110 \mathrm{~kg} / \mathrm{ha}, \mathrm{P} 2 \mathrm{O} 555 \mathrm{~kg} / \mathrm{ha}$ dan $\mathrm{K} 2 \mathrm{O}$ sebanyak $30 \mathrm{~kg} / \mathrm{ha}$ (Ashari, 1995). Menurut Hardjowigeno (2003), bahwa unsure $\mathrm{N}$ berfungsi untuk memperbaiki pertumbuhan vegetative tanaman, seperti akar, batang dan daun. Unsur P berfungsi untuk pembelahan sel, pembentukan bunga, buah dan biji serta, mempercepat pematangan. Selain $\mathrm{N}$ dan $\mathrm{P}$, unsur K juga merupakan unsure hara makro yang berfungsi sebagai unsure penyusun jaringan tanaman, pembentukan pati, serta sebagai activator sebagai enzim yang berperan dalam proses metabolism. 
Jurnal Viabel Pertanian Vol. 10 No.1 April 2016

p-ISSN: 1978-5259 e-ISSN: 2527-3345

Copyright@UNISBA Blitar, http://viabel.unisbablitar.ejournal.web.id

Visca R Yuanita, Tri Kurniastuti \& Palupi Puspitorini, 2016. Respon Pupuk Kandang Kambing

Dan Pupuk Npk Pada Pertumbuhan Dan Hasil Tanaman Terung Hijau (Solanum Melongena L.). Journal Viabel Pertanian. (2016), 10(1) - 53-62

Pemupukan merupakan salah satu upaya yang dapat ditempuh dalam memaksimalkan hasil tanaman. Menurut Wijaya (2008), pemupukan dilakukan sebagai upaya untuk mencukupi kebutuhan hara tanaman agar tujuan produksi dapat dicapai. Namun apabila penggunaan pupuk yang tidak bijaksana atau berlebihan dapat menimbulkan masalah bagi tanaman yang diusahakan, seperti keracunan, rentan terhadap hama dan penyakit, kualitas produksi rendah dan selain itu pula biaya produksi tinggi dan dapat menimbulkan pencemaran.

Usaha yang dapat dilakukan untuk meningkatkan produktivitas tanaman adalah dengan pemberian pupuk baik organic maupun anorganik. Pemberian pupuk bertujuan untuk meningkatkan ketersediaan unsure hara dalam. Pupuk kandang (pupuk organik) merupakan kotoran padat dan cairan yang tercampur dengan sisa-sisa makanan atau alas kandang ternak. Pupuk kandang dapat dikatakan selain mengandung unsur hara makro (nitrogen), fosfor, kalium, dan lain-lain juga mengandung unsur hara mikro (kalsium, magnesium, cuprum serta sejumlah kecil mangan, borium dan lainlain), yang semuanya membentuk pupuk juga menyediakan unsur-unsur hara atau zat - zat makanan bagi kebutuhan dan perkembangan tanaman(Ismawati 2003).

Pupuk NPK merupakan pupuk majemuk yang mengandung unsur hara lebih dari dua jenis. Dengan kandungan unsure hara Nitrogen 15\% dalam bentuk NH3, Fosfor $15 \%$ dalam bentuk P2O, dan kalium $15 \%$ dalam bentuk K2O.

Tujuan penelitian ini adalah untuk mengetahui interaksi antara pemberian pupuk kandang kambing dan pupuk NPK terhadap pertumbuhan dan hasil tanaman terung hijau serta pengaruh masingmasing faktornya

\section{BAHAN DAN METODA}

Penelitian ini dilakukan pada bulan Maret - April 2016. Dilahan milik petani Desa Butun Kecamatan. Gandusari, Kabupaten. Blitar yang berlangsung pada bulan Maret-April 2016. Penelitian ini menggunakan Racangan Acak Kelompok (RAK) Faktorial yang terdiri dari 16 perlakuan dan masing-masing 3 ulangan yaitu : P0M0, P0M1, P0M2, P0M3, P1M0, P1M1, P1M2, P1M3, P2M0, P2M1, P2M2, P2M3, P3M0, P3M1, P3M2, P3M3. Data hasil pengamatan dianalisa secara statistik dengan uji $\mathrm{F}$. Apabila $\mathrm{F}$ hitung lebih besar dari $\mathrm{F}$ tabel $5 \%$ makan dilanjutkan dengan uji Beda Nyata Jujur (BNJ) taraf kesalahan 5\%.

Pengamatan yang dilakukan pada penelitian ini adalah (1) Tinggi tanaman $(\mathrm{cm})$ : Pengukuran tinggi tanaman dilakukan pertanaman unit dengan menggunakan mistar dari pangkal batang sampai pucuk tanaman. Pengukuran tinggi tanaman dimulai sejak berumur 15 hari setelah tanam (HST) sampai awal pembentukan bunga pada tanaman (15, 30, dan 45 HST). (2) Jumlah daun (helai) : Jumlah daun di hitung pada umur 15, 30, dan 45 HST. (3) Panjang buah $(\mathrm{cm})$ : Panjang buah per tanaman sampel diukur dengan mengunakan meteran kain yang dimulai dari pangkal buah sampai ujung buah. Pengukuran dilakukan dengan pengukuran buah secara bersamanan dengan diameter buah setelah panen. (4) Diameter buah $(\mathrm{cm})$ : Diameter buah diukur dengan cara mengukur pada tengah buah. Pengukuran dilakukan setelah panen dengan kriteria buah telah terbentuk sempurna dan buah tidak terbentuk sempurna dan buah tidak termasuk masak. (5) Berat buah per tanaman (g) : Berat buah per tanaman sampel ditimbang dengan timbangan rumah tangga dilakukan setelah panen dengan cara menimbang berat buah setiap tanaman.

\section{HASIL PENELITIAN}

Tinggi tanaman.

Analisis ragam (ANOVA) taraf kesalahan 5\% pada pengamatan 15, 30 dan 45 Hari Setelah Tanam (HST) terdapat interaksi yang sangat nyata antara perlakuan pemberian pupuk kandang kambing 
Jurnal Viabel Pertanian Vol. 10 No.1 April 2016

p-ISSN: 1978-5259 e-ISSN: 2527-3345

Copyright@UNISBA Blitar, http://viabel.unisbablitar.ejournal.web.id

Visca R Yuanita, Tri Kurniastuti \& Palupi Puspitorini, 2016. Respon Pupuk Kandang Kambing

Dan Pupuk Npk Pada Pertumbuhan Dan Hasil Tanaman Terung Hijau (Solanum Melongena L.).

Journal Viabel Pertanian. (2016), 10(1) - 53-62

dengan pupuk NPK terhadap tinggi tanaman terung. Selanjutnya dilakukan Uji BNJ taraf kesalahan $5 \%$ seperti pada tabel 1 dibawah ini.

Tabel 1 Pengaruh kombinasi perlakuan pemberian pupuk kandang kambing dengan pupuk NPK Ponska terhadap tinggi tanaman terung pada umur15, 30 dan 45 HST

\begin{tabular}{llll}
\hline Perlakuan & Tinggi Tanaman $(\mathrm{cm})$ & \\
& $15 \mathrm{HST}$ & $30 \mathrm{HST}$ & $45 \mathrm{HST}$ \\
\hline P0M0 & $23,33 \mathrm{a}$ & $39,66 \mathrm{a}$ & $54,66 \mathrm{ab}$ \\
P0M1 & $24,33 \mathrm{a}$ & $40,33 \mathrm{a}$ & $54,33 \mathrm{a}$ \\
P0M2 & $25 \mathrm{a}$ & $40,66 \mathrm{ab}$ & $54,66 \mathrm{ab}$ \\
P0M3 & $25 \mathrm{a}$ & $41,33 \mathrm{ab}$ & $56 \mathrm{ab}$ \\
P1M0 & $24 \mathrm{a}$ & $43,33 \mathrm{ab}$ & $55,66 \mathrm{ab}$ \\
P1M1 & $24,66 \mathrm{a}$ & $41,33 \mathrm{ab}$ & $55,66 \mathrm{ab}$ \\
P1M2 & $25 \mathrm{a}$ & $43,33 \mathrm{ab}$ & $56,33 \mathrm{ab}$ \\
P1M3 & $23,33 \mathrm{a}$ & $41,66 \mathrm{ab}$ & $56 \mathrm{ab}$ \\
P2M0 & $24,33 \mathrm{a}$ & $43,66 \mathrm{ab}$ & $54,66 \mathrm{ab}$ \\
P2M1 & $25 \mathrm{a}$ & $44,66 \mathrm{~b}$ & $55,66 \mathrm{ab}$ \\
P2M2 & $24,66 \mathrm{a}$ & $44,33 \mathrm{~b}$ & $56,33 \mathrm{ab}$ \\
P2M3 & $28,66 \mathrm{~b}$ & $50 \mathrm{c}$ & $59 \mathrm{c}$ \\
P3M0 & $24,66 \mathrm{a}$ & $44,33 \mathrm{~b}$ & $56,33 \mathrm{ab}$ \\
P3M1 & $25,33 \mathrm{a}$ & $44 \mathrm{~b}$ & $57 \mathrm{bc}$ \\
P3M2 & $25,33 \mathrm{a}$ & $42,66 \mathrm{ab}$ & $55,66 \mathrm{ab}$ \\
P3M3 & $24,66 \mathrm{a}$ & $45,56 \mathrm{~b}$ & $56 \mathrm{ab}$ \\
\hline
\end{tabular}

Keterangan : angka rata-rata yang di ikuti dengan hurup kecil yang sama adalah berbeda tidak nyata berdasarkan hasil uji BNJ taraf 5\% HST= hari setelah tanam

Pada tabel 1 menunjukan bahwa pada 15 HST pemberian kombinasi pupuk kandang kambing 750 $\mathrm{g} /$ tanaman dan pupuk NPK $60 \mathrm{~g} /$ tanaman mampu menambah tinggi tanaman terung sebesar 18,58\% dibandingkan dengan kombinasi tanpa pupuk kandang kambing dan tanpa pupuk NPK. Hal ini diduga pupuk kandang kambing merupakan salahsatu pupuk organik yangbaik sebagai pupuk dasar karena dapat memperbaiki kesuburan tanah, menjaga struktur tanah tetap gembur dan meningkatkan daya serap dan daya pegang tanah terhadap air sehingga ketersediaan air yang dibutuhkan tanaman memadai. Penambahan pupuk organik berupa pupuk kandang kambing dapat memberikan sumbangan hara terutama hara makro dan mikro serta memperbaiki struktur tanah dan biologi tanah sehingga tanaman akan tumbuh optimal.

Hasil penelitian menunjukan pengaruh penggunaan dan pemberian pupuk kandang kambing dan pupuk NPK menunjukkan interaksi yang nyata terhadap rata-rata tinggi tanaman terung hijau pada umur 45 hari setelah tanam.Keadaan ini diduga dengan bertambahnya umur tanaman terung, maka kebutuhan terhadap unsur hara terutama niterogen $(\mathrm{N})$ tidak dapat di penuhi seluruhnya oleh tanah tempat tumbuhnya, sehingga pemberian pupuk kandang kambing dan pupuk NPK dapat meningkatkan ketersediaan dan serapan unsur $\mathrm{N}$ yang sangat dibutuhkan dalam pertumbuhan vegetatif tanaman. Meurut Djoni (2009) mendefinisikan pupuk adalah sumber hara bagi tanaman, sehingga penggunaan pupuk tidak hanya pupuk buatan pabrikan seperti Urea dan NPK tetapi masih banyak sumber hara lainnya. Kotoran ternak dan sisa tanaman bahan hijauan merupakan sumber daya lokal yang potensial dimanfaatkan. Bahan ini jika dimanfaatkan secara optimal tentunya akan dapat menjadi sumber hara bagi tanaman sekaligus mengurangi biaya produksi serta menghilangkan ketergantungan petani pada pihak lain dan mendorong terwujudnya petani hijau lestari. Pupuk kandang mempunyai beberapa sifat yang menguntungkan antaralain sebagai sumber hara nitrogen,fosfor, kalium dan hara mikro yang sangat penting bagi pertumbuhan dan 
Jurnal Viabel Pertanian Vol. 10 No.1 April 2016

p-ISSN: 1978-5259 e-ISSN: 2527-3345

Copyright@UNISBA Blitar, http://viabel.unisbablitar.ejournal.web.id

Visca R Yuanita, Tri Kurniastuti \& Palupi Puspitorini, 2016. Respon Pupuk Kandang Kambing Dan Pupuk Npk Pada Pertumbuhan Dan Hasil Tanaman Terung Hijau (Solanum Melongena L.). Journal Viabel Pertanian. (2016), 10(1) - 53-62

perkembangan tanaman. Sehingga dengan tersedianya unsur $\mathrm{N}$ pada pupuk kandang kambing dan $\mathrm{N}$ pada pupuk NPK dapat memacu pertumbuhan tinggi tanaman terung.

Jumlah Daun.

Analisis ragam (ANOVA) taraf kesalahan 5\% pada pengamatan15, 30 dan 45 Hari Setelah Tanam (HST) terdapat interaksi yang sangat nyata antara perlakuan pemberian pupuk kandang kambing dengan pupuk NPK (PM) pada variabel jumlah daun terung hijau. Selanjutnya dilakukan Uji BNJ taraf kesalahan 5\% seperti pada tabel 2 dibawah ini.

Tabel 2 Pengaruh kombinasi pemberian pupuk kandang kambing dan pupuk NPK terhadap jumlah daun tanaman terung pada umur 15,30 dan 45 HST

Keterangan : angka keKeterangan : angka rata-rata yang di ikuti dengan hurup kecil yang sama adalah berbeda tidak nyata berdasarkan hasil uji BNJ taraf 5\% HST= hari setelah tanam.

\begin{tabular}{llll}
\hline \multirow{2}{*}{ Perlakuan } & \multicolumn{2}{l}{ Jumlah Daun (helai) } \\
& $15 \mathrm{HST}$ & $30 \mathrm{HST}$ & $45 \mathrm{HST}$ \\
\hline P0M0 & $7,66 \mathrm{a}$ & $12,33 \mathrm{~b}$ & $13 \mathrm{a}$ \\
P0M1 & $7,66 \mathrm{a}$ & $11,66 \mathrm{ab}$ & $11,66 \mathrm{a}$ \\
P0M2 & $8,33 \mathrm{a}$ & $10,33 \mathrm{a}$ & $11,33 \mathrm{a}$ \\
P0M3 & $7,66 \mathrm{a}$ & $10,66 \mathrm{ab}$ & $11,66 \mathrm{a}$ \\
P1M0 & $8 \mathrm{a}$ & $10,33 \mathrm{a}$ & $11,33 \mathrm{a}$ \\
P1M1 & $7,33 \mathrm{a}$ & $10,33 \mathrm{a}$ & $11,33 \mathrm{a}$ \\
P1M2 & $8,33 \mathrm{a}$ & $11 \mathrm{ab}$ & $12 \mathrm{a}$ \\
P1M3 & $7,33 \mathrm{a}$ & $10,33 \mathrm{a}$ & $11,33 \mathrm{a}$ \\
P2M0 & $8,66 \mathrm{ab}$ & $10,33 \mathrm{a}$ & $11,66 \mathrm{a}$ \\
P2M1 & $7,33 \mathrm{a}$ & $11,66 \mathrm{ab}$ & $12,66 \mathrm{a}$ \\
P2M2 & $7,33 \mathrm{a}$ & $10,66 \mathrm{ab}$ & $12,33 \mathrm{a}$ \\
P2M3 & $9,66 \mathrm{~b}$ & $13,66 \mathrm{~b}$ & $15,66 \mathrm{~b}$ \\
P3M0 & $7,66 \mathrm{a}$ & $11,66 \mathrm{ab}$ & $12,66 \mathrm{a}$ \\
P3M1 & $8,66 \mathrm{ab}$ & $10,66 \mathrm{ab}$ & $13 \mathrm{a}$ \\
P3M2 & $8,33 \mathrm{a}$ & $10,33 \mathrm{a}$ & $12,66 \mathrm{a}$ \\
P3M3 & $8,66 \mathrm{ab}$ & $11 \mathrm{ab}$ & $13 \mathrm{a}$ \\
\hline
\end{tabular}


Jurnal Viabel Pertanian Vol. 10 No.1 April 2016

p-ISSN: 1978-5259 e-ISSN: 2527-3345

Copyright@UNISBA Blitar, http://viabel.unisbablitar.ejournal.web.id

Visca R Yuanita, Tri Kurniastuti \& Palupi Puspitorini, 2016. Respon Pupuk Kandang Kambing

Dan Pupuk Npk Pada Pertumbuhan Dan Hasil Tanaman Terung Hijau (Solanum Melongena L.). Journal Viabel Pertanian. (2016), 10(1) - 53-62

Hasil Analisis ragam (ANOVA) taraf kesalahan 5\% pada jumlah daun tanaman terung hijau menunjukkan bahwa pada 15, 30 dan 45 Hari Setelah Tanam terdapat interaksi yang sangat nyata antara perlakuan pemberian pupuk kandang kambing dengan pupuk npk terhadap jumlah daun tanaman terung hijau. Pemberian pupuk kandang kambing $750 \mathrm{~g} /$ tanaman dan pupuk npk60 g/tanaman sangat nyata berpengaruh pada pertambahan jumlah daun pada 15,30 dan 45 Hari Setelah Tanam.

Bertambahnya umur tanaman terung hijau, maka kebutuhan tanaman akan bertambah banyak dan unsur hara dalam tanah tidak akan mampu memenuhi kebutuhannya sehingga akan berpengaruh terhadap pertumbuhan. Dengan pemberian pupuk kandang kambing dan pupuk NPK mampu menambah ketersediaan unsur hara $\mathrm{N}$ yang sangat dibutuhkan untuk pertumbuhan vegetatif tanaman. Prihmantoro (1999) mengemukakan bahwa pada pertumbuhan vegetatif tanaman seperti pembentukan batang, cabang dan daun serat pembentukan klorofil diperlukan adanya unsur hara $\mathrm{N}$. Meningkatkan pemberian pupuk secara optimum dengan terus menerus akan menaikkan kapasitas produktif tanah, sehingga tanaman yang dihasilkan akan berpotensi lebih baik.

Menurut Roeslan, (2004) mengemukakan bahwa bahan organik seperti pupuk kandang dapat sebagai sumber humus, sumber hara makro dan mikro dan pembawa mikroorganisme yang menguntungkan dan juga sebagai pemacu pertumbuhan tanaman. Sehingga penambahan pupuk organik berupa pupuk kandang kambing disamping menambah unsur hara bagi tanaman juga mencitakan kondisi yang sesuai bagi pertumbuhan tanaman.

Panjang Buah.

Hasil Analisis ragam (ANOVA) taraf kesalahan 5\% pada variabel panjang buah panen terdapat interaksi yang sangat nyata antara perlakuan pemberian pupuk kandang kambing dan pupuk NPK(PM) terhadap panjang buah terung hijau. Selanjutnya dilakukan Uji BNJ taraf kesalahan 5\% seperti pada tabel 3 dibawah ini.

Tabel 3 Pengaruh kombinasi pemberian pupuk kandang kambing dan pupuk npk terhadap panjang buah terung hijau.

\begin{tabular}{ll}
\hline Perlakuan & Panjang Buah $(\mathrm{cm})$ \\
\hline P0M0 & $20,00 \mathrm{a}$ \\
P0M1 & $21.00 \mathrm{ab}$ \\
P0M2 & $21,67 \mathrm{ab}$ \\
P0M3 & $23.00 \mathrm{ab}$ \\
P1M0 & $24,33 \mathrm{~b}$ \\
P1M1 & $26,66 \mathrm{~b}$ \\
P1M2 & $26.00 \mathrm{~b}$ \\
P1M3 & $26,66 \mathrm{~b}$ \\
P2M0 & $27.00 \mathrm{~b}$ \\
P2M1 & $25,67 \mathrm{~b}$ \\
P2M2 & $26.00 \mathrm{~b}$ \\
P2M3 & $34,33 \mathrm{c}$ \\
P3M0 & $27,33 \mathrm{~b}$ \\
P3M1 & $27.00 \mathrm{~b}$ \\
P3M2 & $22,67 \mathrm{ab}$ \\
P3M3 & $23,66 \mathrm{ab}$ \\
\hline KM
\end{tabular}

Keterangan : angka rata-rata yang di ikuti dengan hurup kecil yang sama adalah berbeda tidak nyata berdasarkan hasil uji BNJ taraf 5\% 
Jurnal Viabel Pertanian Vol. 10 No.1 April 2016

p-ISSN: 1978-5259 e-ISSN: 2527-3345

Copyright@UNISBA Blitar, http://viabel.unisbablitar.ejournal.web.id

Visca R Yuanita, Tri Kurniastuti \& Palupi Puspitorini, 2016. Respon Pupuk Kandang Kambing

Dan Pupuk Npk Pada Pertumbuhan Dan Hasil Tanaman Terung Hijau (Solanum Melongena L.). Journal Viabel Pertanian. (2016), 10(1) - 53-62

Pada Tabel 3 menunjukkan bahwa kombinasi perlakuan pemberian pupuk kandang kambing dengan dosis $750 \mathrm{~g} /$ tanaman dan $60 \mathrm{~g} /$ tanaman (P2M3)sebesar 34,33 $\mathrm{cm}$ memberikan pengaruh yang nyata terhadap panjang buah terunghijau dibandingkan dengan perlakuan yang lain. Pada variabelpanjang buah terung hijau hasil terkecil ditunjukkan oleh kombinasi perlakuan tanpa pupuk kandang kambing dan tanpa pupuk NPK (kontrol) yaitu sebesar $20 \mathrm{~cm}$.

Pemberian kombinasi pupuk kandang kambing pada level pemberian dosis $750 \mathrm{~g} /$ tanaman dan pupuk NPK $60 \mathrm{~g} / \operatorname{tanaman}$ (P2M3) nyata meningkatkan panjang buah terung hijau sebesar 41,74\% dibandingkan dengan kombinasi tanpa pupuk kandang kambing dan tanpa pupuk NPK (kontrol).

Diameter Buah

Analisis ragam (ANOVA) taraf kesalahan 5\% pada pengamatan diameter buah terung hijau tidak terdapat interaksi yang nyata antara perlakuan pemberian pupuk kandang kambing dengan pupuk NPK (PM) terhadap diameter buahterung hijau. Namun pada faktor pemberian pupuk kandang kambing $(\mathrm{P})$ terdapat perbedaan yang sangat nyata begitu juga pada faktor pemberian pupuk NPK terdapat perbedaan yang nyata. Selanjutnya dilakukan Uji BNJ taraf kesalahan 5\% seperti pada tabel 4 dibawah ini.

Tabel 4 Pengaruh pemberian pupuk kandang kambing dan pupuk NPK terhadap diameter buah terung hijau

\begin{tabular}{ll}
\hline Perlakuan & Hasil $(\mathrm{cm})$ \\
\hline P0 & 3,67 a \\
P1 & 4,17 ab \\
P2 & 4,83 b \\
P3 & 4,67 b \\
\hline Perlakuan & Hasil $(\mathrm{cm})$ \\
\hline M0 & 4,08 ab \\
M1 & 4,42 ab \\
M2 & 4,00 a \\
M3 & 4,83 b
\end{tabular}

Keterangan : angka rata-rata yang di ikuti dengan hurup kecil yang sama adalah berbeda tidak nyata berdasarkan hasil uji BNJ taraf 5\%

Hasil Analisis ragam (ANOVA) taraf kesalahan 5\% diameter buah terung hijau menunjukkan bahwa tidak terdapat interaksi yang nyata pada kombinasi perlakuan pemberian pupuk kandang kambing dengan pupuk npkterhadap diameter buah terung hijau. Namun menunjukkan hasil yang berbeda pada masing-masing faktor. Faktor pemberian pupuk kandang kambing memberikan perngaruh sangat nyata terhadap diameter buah terung hijau, sedangkan faktor pemberian pupuk NPK memberikan pengaruh yang nyata.

Faktor perlakuan pemberian pupuk kandang kambing750g/ tanaman (P2)dan faktor pupuk NPK 60 g/tanaman (M3)merupakan hasil yang terbaik terhadap diameter buahterung hijau dibandingkan dengan lainnya. Namun pada faktor pemberian pupuk kandang kambing $1000 \mathrm{~g} /$ tanaman juga menunjukkan hasil yang baik, dengan diameter buah 4,67 cm dan mampu meningkatkan diameter buah sebesar $21,41 \%$ dibandingkan tanpa pemberian pupuk kandang kambing (P0). Sedangkan penggunaan pupuk kandang kambing dengan dosis $750 \mathrm{~g} /$ tanaman menunjukkan diameter 4,83 cmdan mampu meningkatkan diameter buah sebesar 24,02\% dibandingkan tanpa pemberian pupuk kandang kambing (P0). Hal ini diduga bahwa media tanaman yang mengandung unsur hara yang 
Jurnal Viabel Pertanian Vol. 10 No.1 April 2016

p-ISSN: 1978-5259 e-ISSN: 2527-3345

Copyright@UNISBA Blitar, http://viabel.unisbablitar.ejournal.web.id

Visca R Yuanita, Tri Kurniastuti \& Palupi Puspitorini, 2016. Respon Pupuk Kandang Kambing

Dan Pupuk Npk Pada Pertumbuhan Dan Hasil Tanaman Terung Hijau (Solanum Melongena L.). Journal Viabel Pertanian. (2016), 10(1) - 53-62

cukup, mampu memenuhi kebutuhan tanaman terung hijau sehingga dapat meningkatkan hasil panen tanaman.

Bobot Segar Pertanaman

Analisis ragam (ANOVA) taraf kesalahan 5\% pada pengamatan setelah dilakukan panen terdapat interaksi yang sangat nyata antara perlakuan pemberian pupuk kandang kambing dan pupuk NPK(PM) terhadap berat segar per tanaman terung hijau. Selanjutnya dilakukan Uji BNJ taraf kesalahan 5\% seperti pada tabel 5 dibawah ini.

Tabel 5 Pengaruh kombinasi pemberian pupuk kandang kambing dan pupuk npk terhadap berat segar pertanaman terung hijau.

\begin{tabular}{llc}
\hline Perlakuan & \multicolumn{2}{l}{ Berat Segar Pertanaman $(\mathrm{g})$} \\
\hline P0M0 & 716,60 & $\mathrm{a}$ \\
P0M1 & 870.00 & ab \\
P0M2 & 910.00 & $\mathrm{~b}$ \\
P0M3 & 953,30 & bc \\
P1M0 & 923,30 & bc \\
P1M1 & 980.00 & bc \\
P1M2 & 1193,30 & cd \\
P1M3 & 1183,30 & cd \\
P2M0 & 1226,60 & cd \\
P2M1 & 1270.00 & cd \\
P2M2 & 1266,60 & cd \\
P2M3 & 1576,60 & e \\
P3M0 & 1113,30 & $\mathrm{c}$ \\
P3M1 & 1303,30 & d \\
P3M2 & 1386,60 & d \\
P3M3 & 1230.00 & cd \\
\hline
\end{tabular}

Keterangan : angka rata-rata yang di ikuti dengan hurup kecil yang sama adalah berbeda tidak nyata berdasarkan hasil uji BNJ taraf 5\%

Hasil Analisis Ragam (Anova) berat segar pertanaman terung hijau menunjukkan bahwa terdapat interaksi yang sangat nyata antara perlakuan pemberian pupuk kandang kambing750 g/ tanamandan pupuk NPK $60 \mathrm{~g} / \operatorname{tanaman}(\mathrm{P} 2 \mathrm{M} 3)$ terhadap berat segar pertanaman terung hijau. Perlakuan pemberian pupuk kandang kambing 750g/ tanamandan pupuk NPK 60 $\mathrm{g} / \operatorname{tanaman}(\mathrm{P} 2 \mathrm{M} 3)$ merupakan hasil yang terbaik terhadap bobot segar pertanaman terung hijau yaitu sebesar 1576,6 gram dan mampu meningkatkan berat hingga 54,55\% dibandingkan kombinasi tanpa pemberian pupuk kandang kambing dan tanpa pupuk NPK (P0M0). Hal ini diduga bahwa dengan pemberian pupukkandang kambing dengan pemberian pupuk NPKdapat meningkatkan bobot segar tanaman terung hijau karena pupuk tersebut mengandung unsur Nitrogen, Fosfor, Kalium yang terpenuhi serta selain memberikan sumbahan unsur hara makro dan mikro pada tanaman juga mampu memperbaiki sifat fisik dan biologi tanah, sehingga mampu meningkatkan produktifitas tanaman.

Hal ini didukung pendapat Rosmarkan, (2002) bahwa faktor kesuburan tanah sangat mendukung dalam peningkatan pertumbuhan dan produksi tanaman, disamping itu juga diperlukan aerasi dan draenase tanah yang baik. Pemberian pupuk organik selain meningkatkan kapasitas tukar kation juga mampu meningkatkan kesuburan tanah menyimpan air, sehingga unsurhara yang ada didalam 
Jurnal Viabel Pertanian Vol. 10 No.1 April 2016

p-ISSN: 1978-5259 e-ISSN: 2527-3345

Copyright@UNISBA Blitar, http://viabel.unisbablitar.ejournal.web.id

Visca R Yuanita, Tri Kurniastuti \& Palupi Puspitorini, 2016. Respon Pupuk Kandang Kambing

Dan Pupuk Npk Pada Pertumbuhan Dan Hasil Tanaman Terung Hijau (Solanum Melongena L.).

Journal Viabel Pertanian. (2016), 10(1) - 53-62

tanah dan yang ditambahkan dari luar tidak mudah larut dan hilang. Dengan demikian pemberian pupuk organik dan pupuk buatan secara kombinasi sangat diperlukan untuk meningkatkan pertumbuhan dan produksi tanaman. Selain itu pemberian pupuk organik yang seimbang dan dipadukan dengan penggunaan pupuk buatan dapat meningktkan produktifitas tanaman dan efisiensi penggunaan pupuk. Tanaman tidak akan menunjukkan hasil panen yang maksimal apabila kebutuhan unsur hara tidak tersedia, sehingga pemberian pupuk NPK dapat meningkatkan hasil panen secara kuantitatif dan kualitatif. Banyumas, (2011) mengemukakan bahwa kandungan Nitrogen berguna untuk menghasilkan banyak bahan hijau berupa daun dan batang. Sehingga merupakan unsur yang penting untuk pertumbuhan tanaman secara umum. Unsur nitrogen terutama diperlukan pada fase vegetatif yang berperan dalam pembentukan klorofil, asam amino, enzim dan pesenyawa lain. Nitrogen diserap oleh tanaman hampir seluruhnya dalam bentuk nitrat (NO3-) atau garam amonium (NH4+). Tanaman yang mengalami kekurangan nitrogen memperlihatkan gejala pertumbuhan tanaman kerdil dan menguning. Unsur fosfor berperan pada pembiakan generatif

, bagi tanaman membantu pembentukan protein dan mineral yang berguna untuk merangsang pertumbuhan akar, membantu asimilasi dan respirasi, serta mempercepat pembungaan, pemasakan biji, dan buah. Sesuai dengan pendapat Setyamidjaja, (1990) bahwa Fosfor berperan mempercepat pembungaan, pemasakan buah dan biji. Kekurangan fosfor menyebabkan pertumbuhan akar tanaman lambat, tanaman kerdil, daun berwarna hijau dan tegak. Kalium merupakan unsur esensial yang dibutuhkan dalam jumlah besar oleh tumbuhan setelah nitrogen. Kalium membantu pembentukan protein, karohidrat dan gula, membantu pengangkutan gula dari daun ke buah, memperkuat jaringan tanaman serta meningkatkat daya tahan tanaman terhadap penyakit.

Sarno, (2009) mengemukakan bahwa kombinasi pemupukan antara pupuk organik dan pupuk buatan penting diberikan dibandingkan hanya pupuk buatan saja, karena kombinasi puuk organik dan pupuk buatan dapat meningkatkan hasil pada tanaman terung hijau. Selanjutnya menurut Haryanto et al (2006) kandungan bahan organik yang rendah merupakan kendala utama dalam produksi sayur-sayuran. Oleh karena itu untuk mendapatkan produksi sayuran yang tinggi, disamping pemberian pupuk kimia juga harus dilakukan pemberian pupuk organik.

\section{KESIMPULAN}

Pengaruh kombinasi pemberian pupuk kandang kambing dan pupuk NPK menunjukkan interaksi yang sangat nyata terhadap tinggi tanaman dan jumlah daun tanaman terung hijau pada 15, 30 dan 45 HST serta pada panjang buah dan bobot segar pertanaman terung hijau. Kombinasi perlakuan yang paling baik ditunjukan oleh pemberian pupuk kandang kambing dengan dosis 750 $\mathrm{g} / \operatorname{tanaman}$ dan pupuk NPK $60 \mathrm{~g} / \operatorname{tanaman}$ (P2M3) dengan bobot buah pertanaman sebesar 1.576,6 gram serta meningkatkan hasil mencapai 54,55\% dibandingkan dengan perlakuan kontrol.

Pemberian pupuk kandang kambing memberikan pengaruh yang sangat nyata meningkatkan diameter buah terung hijau. Pupuk kandang kambing dengan dosis $750 \mathrm{~g} / \operatorname{tanaman}$ (P2) menunjukkan hasil 4,83 cm, meningkat 24,02\% dibandingkan dengan perlakuan kontrol.

Pemberian pupuk NPK memberikan pengaruh yang nyata terhadap diameter terung hijau. Pupuk NPK dengan dosis $60 \mathrm{~g} /$ tanaman (M3) menunjukkan hasil 4,83 cm meningkat 17,18\% dibandingkan dengan dosis pupuk NPK $40 \mathrm{~g} / \operatorname{tanaman}(\mathrm{M} 2)$.

\section{PUSTAKA}


Jurnal Viabel Pertanian Vol. 10 No.1 April 2016

p-ISSN: 1978-5259 e-ISSN: 2527-3345

Copyright@UNISBA Blitar, http://viabel.unisbablitar.ejournal.web.id

Visca R Yuanita, Tri Kurniastuti \& Palupi Puspitorini, 2016. Respon Pupuk Kandang Kambing Dan Pupuk Npk Pada Pertumbuhan Dan Hasil Tanaman Terung Hijau (Solanum Melongena L.). Journal Viabel Pertanian. (2016), 10(1) - 53-62

Djoni. 2009. Pertanian Organik (Kehidupan adalah Hidup yang Organik, Sejahtera, Sehat dan Lestari). Padang: 160 hal.

Roeslan, A. 2004. Pengaruh Penggunaan Pupuk Organik Terhadap Pertumbuhan dan Hasil Bawang (Allium Cepa L. Var Ascalonicum. Jurnal Budidaya Pertanian 10 (2) 73-78.

Rosmarkam, A dan N.W. Yuworo. 2002. Ilmu Kesuburan Tanah. Kanisius: Yogyakarta.

Banyumas. (2011). Kandungan Pupuk Pada Kotoran Hewan tersedia dalam http: //banyumas.blogspot.com/2011/08/kandungan-pupuk-pada-kotoran-hewanhtm. [Diakses 25 Januari 2014].

Setyamidjaya. 1990. Pupuk dan Pemupukan. CV Simplek. Jakarta: 122 hal.

Sarno. 2009. Pengaruh Kombinasi NPK dan Pupuk Kandang terhadap Sifat Tanah dan Pertumbuhan serta Produksi Tanaman Caisim. Jurnal Tanah Tropika. Vol 14 no. 3.211-219. 